UDC 811.111

DOI https://doi.org/10.32447/2663-340X-2018-4-39-43

\title{
STYLISTIC FEATURES OF ENGLISH ADVERTISING SLOGANS
}

\author{
Maryna Zembytska, Yulia Mazur \\ Candidates of Pedagogical Sciences, associate professors at \\ the Department of Foreign Language Practice and Teaching Methods, \\ Khmelnytskyi National University, Instytutska Str., 11, Khmelnytskyi, Ukraine
}

\begin{abstract}
The study focuses on the basic linguistic features of advertising slogans and linguistic toolsthat, which are most frequently used at morphological, lexical and syntactic levels. Stylistic devices utilized in modern English commercial advertising. The current paper reveals research findings from the analysis of over 100 randomly selected advertising slogans, which are analyzed in terms of their structure and lexis. The study involves a number of criteria set for an effective advertisement: attention value, listening ability/readability, memorability, and marketing power, as well as the requirements to be met: conciseness accompanied with intensive emotion; focus on the core commercial proposal; simple language that is easily memorized and easily translated. Particular attention is drawn to the persuasive power of advertising textsand their influence on the recipients, which is the result of relevantly chosen stylistic devices, figures of speech and tropes. Two basic approaches to the linguistic analysis of advertisementsare speculated upon, i.e. sociolinguistic approach and psycholinguistic approach. Both examined approaches suggest that there is certain interdependence between the persuasive power of advertisements and the utilized linguistic tools. The study of the selected advertisements reveals the following groups of stylistic devices at different language levels. In particular, at the phonological level: antisthecon, onomatopoeia, consonance, assonance, alliteration; at the syntactical level: anthimeria, epistrophe, anaphora; at the semasiological level: ellipsis, chiasmus, antithesis, hyperbole, simile, metaphor, rhetorical questions, semantic ambiguity, polysemy and puns. The stylistic devices used in advertising are classified into: stylistic devices involving repetition; stylistic toolscreating a metaphorical situation that provokes a recipient's reaction; complex stylistic resources involving both repetition and semantic variation. The study also attempts to reveal particular aspects of advertising discourse perception and interpretation.
\end{abstract}

Key words: advertisement, slogan, stylistic device, figure of speech/rhetorical figure, trope, advertising discourse.

Introduction. Despite the increased interest of linguists to the verbal component of advertisement, some of its linguistic and extralinguistic features are often disregarded in translation. Therefore, the study of stylistic aspects of English commercial advertising is of great scientific and practical value. The suggested study is based on a corpus of more than one hundred commercial advertisements found in the English segment of the Internet.

Theoretical framework. The current body of research gives insufficient evidence of theoretical and empirical studies specifically covering the stylistic features of English commercial advertising slogans and tackling their translation issues. Researchers have mainly focused on general pragmatic aspects of advertising and its capacity to persuade potential customers. Some aspects of advertising discourse and the problems associated with its translation have been studied by G. Cook, T. Dubitsky, M. Geis, R. Harris, K. Jo Bruno, R. Klink, G. Leech, D. Miller, G. Myers, N. Rees, K. Tanaka, M. Toman, I. Torresi, L. Wu, et al.

The purpose of the study. The study aims to explore the stylistic features of English commercial advertising slogans. The practical part of the paper is an attempt to exemplify the most common stylistic devices and rhetorical figures used in the language of

(C) Zembytska Maryna, Mazur Yulia. Stylistic features of English advertising slogans
advertisement.The specific objectives of the present study are: a) to provide an overview of linguistic and extralinguistic tools used in commercial advertising; b) to characterize thestylistic devices and rhetorical figures found in the selected slogans; c) to define the problems associated with their translation into Ukrainian.

Research findings. The complexity of advertising language is manifested through a wide range of attention-seeking (attention-catching) devices which can be of both linguistic and extralinguistic nature. One of the effective attention-seeking devicesin advertisements is unusual spelling. Copywriters often produce advertising texts which contain deviations from the standards of normative spelling and grammar to increase the recipients' attention by confronting with something unexpected. The strategies of catching attention can vary - an advert can be pleasing, stirring up curiosity, shocking, deliberately upsetting or intentionally irritating.Even with minor deviations, these texts are still comprehensible and easy to decode for the reader, e.g. "Eat MorChikin!' (Chick-fil-A).

The 2013 advertisement by Snickers purposefully misspelled the brand's name and included a number of other intentional spelling mistakes to convince the intended audience that grabbing a Snickers can help to concentrate while working on a computer or doing something important: "Snikkers. OHDEER. It's hard to spel when your hungry. If youkeap making typing mistakes grab yourself a Snickers fast". Deviation and 
parallelism are the basic ways in which foregrounding in advertising discourse can be achieved $[2,158]$.

According to G. Leech [5],effective advertising meets a number ofcriteria, such as attention value, listeningability/readability, memorability, and marketing power. Stylistic figures and tropes, such asalliteration, onomatopoeia, ellipsis, metaphor,paradox, etc.correspond to attention value and memorability. Simple and informal sentences are associated withreadability. Other linguistic techniques (intensive use of imperatives, superlatives, inversions, and parallelism, etc.) conform to marketing power $[5,98]$.

Decoding of advertising discourse consists of a dynamic interplay of internal components (e.g. language, image, products, price, quality, discourse structure) and external communication between readers and advertisers [3, 122].

With this idea in mind two basic approaches to linguistic analysis of advertisement may be singled out:a) sociolinguistic approach; b) psycholinguistic approach. H. Liu's [7] in-depth analysis of the sociolinguistic approach to advertising characterizes the advertising language as a system performing two basic functions: the indexical function to name the product, and the ideological function of adding new meaning to the product. Taking Malboro advertisement as an example, the researcher explains that the indexical function is manifested in Malboro referring to the product, the cigarettes, while the ideological function of Malboro is expressing the value of bourgeois masculinity and therefore adding value to the product [7, 76-78]. G. Dyer [3, 123] sees advertising as a system which consists of distinct signs conveying the ideological meaning. These are symbols, such as white colour which signifies purity. Therefore, semantic analysis of advertising discourse should involve both denotation (literal meaning) and connotation (the meanings beyond).

Within the psycholinguistic approach, researchers [1] specify such types of advertisementsas: "reason advertisement" and "tickle advertisement". Reason ads suggest motives for purchase, while tickle advertisements appeal to the recipient's emotion, humor, and mood. Advertisements can be classified by the utilized advertising techniques: "hard-sell advertisement" and "soft-sell advertisement". Hard selling suggests a direct appeal to the recipient, while soft selling relies on mood rather than exhortation $[1,15]$.

Both abovementioned approaches suggest that there is certain interdependence between the persuasive power of advertisements and the utilized linguistic tools. Advertising discourse differs from other types of discourse by its functional and communicative parameters, as well as its specific regulated structure. Complex advertising texts involve such componentsas: the title, the main advertising text, and the slogan. The focal pointof their structure is the title, which is a kind of appeal to the consumer, while a slogan is a sort of an advertising summary, which is supposed to produce the greatest effect on the recipient. In wider contexts, a slogan is defined as any short catchy phrase appearing in the advertisement or unique phrase identified with a company or brand $[9,49]$.

An effective slogan should meet the following requirements: a) conciseness accompanied with intensive emotion, which promises to satisfy the consumer's needs; b) focus on the core commercial proposal; c) simple language that is easily memorized and easily translated. A successful slogan is often a short self-contained advertising message which can be used as an independent piece of text in isolation from other advertising products. These requirements are met by a combination of linguistic and extralinguistic devices applied on different levels.

According to the findings obtained through the literary analysis and interpretation of selected advertising slogans written in English, the following linguistic tools are most frequently utilized at morphological, syntactic and lexical levels:

1) initial and full capitalization which is supposed to attract more attention or to stress every single word in a slogan: e.g. "I Love What You Do For Me" (Toyota); "CALIFORNIA'S BEST BEER". The format of the text can make a difference. Italics is considered to be more personal and individualistic. Various styles of italics, various fonts, styles and sizes are likely to have subtly different readings.

2) common use of the second person addressee "you", which approximates the product to the consumer, making the message more genuine: e.g. "It's everywhere you want to be" (Visa); "You get fresh, hot pizza delivered to your door in 30 minutes or less-or it's free" (Domino's Pizza); "Be all that you can be" (United States Army); "It Could Be You" (the National Lottery);

3) wide use of such pronouns and adverbs as "every", "everything", "everyone", "always". E.g. "Everyone loses games. Few change them" (Nike);"Challenge everything" (Electronic arts); "Everything is easier on a Mac" (Apple Computer); "In here, It's Always Fridays" (Friday's); "Always Coca-Cola". These words are often used in advertisementto convey the idea of product versatility, its ultimate necessity, or to address the widest range of potential customers by emphasizing spirit of inclusiveness;

4) coinage - the use of coined words (neologisms) created by means of affixation, conversion, blending, clipping, abbreviation, condensation, compounding, reduplication, borrowing E.g.: "Get Skintimate with your legs" (Skintimate); "The goddess of never-letme-go" (Venus); "Why settle for any other $A C$ when you can get a DAIKIN? (an example of acronym; DAIKIN Air-conditioner);

5) binary connectives: two parts (words, phrases, clauses, or sentences; usually concise in form) which are opposed to each other: "Walk in. Drive out" (SBI Car Loans); "Your vision. Our future" (Olympus);

6) short simple sentences that are easy to remember: e.g. "We are the low-fare airline." (Southwest Airlines); "You get rid of dandruff" (Head \& Shoulders). Among all the tenses, it is the Present Simple that is most frequently used in advertisement: "The sneaker 
makes the man" (Nike); "Where there is trust, reassurance follows" (LIC Finance Ltd.). The Future Simple is preferred to create the atmosphere of temporal closeness to the consumer: e.g.; "We'll leave a light on for you" (Motel 6);

7) one-member and nominative sentences: "Like no place else" (Chili's restaurant); "Dishing it out" (Dish TV); "Got Milk?" (California Milk Processor Board); "A world in peace, not in pieces"; "Because simple isn't easy". Advertisers tend to use disjunctive grammar in advertising slogans in order to make the advertising language more distinct. One-member and nominative sentences compress an advertisement text and its message to the limit and thus make the advertisingslogan extremely catchy. E.g.; "The Few. The Proud. The Marines" (U.S. Marine Corps);

8) negative statements: e.g. "M\&Ms melt in your mouth, not in your hand"; "Sometimes you feel like a nut, sometimes you don't" (Peter Paul Almond Joy \& Peter Paul Mounds); "It's not TV, it's HBO" (HBO); "There is no substitute" (Porsche); "Please Don't Squeeze the Charmin" (Charmin Toilet Paper). Negative particles "no", "not" are used to emphasize the positive side of the product;

9) imperatives: e.g. ."Life is a journey, travel it well" (United Airlines); "Make believe" (Sony). Imperatives leave people little room for argument, encouraging them to buy the product without hesitating: "Obey your thirst" (Sprite); "Think different" (Apple); "Buy it. Sell it. Love it." (Ebay); "Play on" (Lego); "Have it your way" (Burger King). Research findings by G. Myers prove that imperative, exclamatory, and interrogative sentences often predominate over those of the declarative type $[8,54]$ (such as the declarative sentence "You will love the skin you are in" by Olay.)

10) conditional clauses are used to stimulate therecipient's logical deduction: "If you want to impress someone, put him on your black list" (Johnie Walker); "Ifyou died young, who'd pay the bills?" (G Ensurance);

11) inversion immediately draws the recipient's attention to what is being advertised: e.g. "Opportunity you can 't afford to miss" (TDI Centre Jalandhar); "Impossible is nothing" (Adidas);

12) the comparative and superlative degrees of adjectives and adverbs emphasize the strengths of the product. E.g."Most aces. Most games. Longest Match" (Nike); "Stronger than dirt"(Ajax); "The happiest place in Earth" (Disneyland); "We try harder" (Avis); "Better Ingredients, Better Pizza" (Papa John's); "Make the most of now" (Vodafone); "It's Way Better than Fast Food. It's Wendy's" (Wendy's fast food). Companies tend to choose unqualified comparison to avoid advertising their products at the expense of others: e.g. "Better choice, better joys" (Coleman footgear);

One of the most effective techniques to make the brand name memorable is to make it rhyme with the corresponding slogan: e.g. "Don't be vague. Ask for Haig" (Haig Scotch). The brand name is often placed in postposition or is omitted in the rhyme: "When the shoes get lighter, the moves get tighter" (Nike); "The snack that smiles back" (Goldfish); "Journey is in Doubt if the Ticket is from a Tout" (Northern Railway). The stylistic devices used in advertising can be classified into: 1) stylistic resources involving the repetition of some element. Repetition is a basic strength factor and a primordial element of cognition, which makes it easier to recall the brand slogan; 2) stylistictools that create a metaphorical situation that provokes a reaction in the recipient; and 3 ) stylistic resources based on both the repetition of a linguistic unit and semantic variation.

By studying a selection of over 100 online commercial advertising slogans written in English we were able to specify their stylistic features. The following stylistic deviceswere most frequently usedat the phonological level:

a) alliteration: e.g. "For the Men in Charge of Charge" (Fortune Magazine); "Fila: Functional... Fashionable... Formidable" (Fila); "Pleasing people the world over" (Holiday Inn); "The daily diary of the American dream" (Wall Street Journal); "Good time to Grab Golden Opportunity on 11.11.11" (Advertisement of BCL Homes at Mohali); "Don't dream it. Drive it" (Jaguar); "Totally Terrific Tuesdays" (BramptonGuardian); "Everything's better with Blue Bonnet on it" (Blue Bonnet margarine). The repetition of a consonant sound, usually at the beginning of a word, three or more times makes the slogan more memorable and produces a strong beating rhythm;

b) assonance: repetition of the same or similar vowels in the stressed syllables of words that are in close proximity. E.g. "Grace, space, pace" (Jaguar);

c) consonance: a poetic device that uses the repetition of the same consonant two or more times in rapid succession, e.g. "The Quicker Picker Upper"( Bounty); "Ariston... and on ... and on ..." (Ariston);

d) onomatopoeia: "Plop, Plop, Fizz, Fizz, oh what a relief it is" (Alka-Seltzer); "Mmmm .... Smells good! Uflex?" (UFLEX Flexible Packaging); "Snap! Crackle! Pop!" (Rice Krispies); "Red Bull gives you wiiings"; "They're Gr-r-reat" (Kellogg's Frosted Flakes);

e) antisthecon - substitution of a letter for another letter, often to create irony,which makes the recipient stop and think about the meaning or even guess it. E.g. "A mind is a terrible ting to waste" (UNCF).

At the syntacticallevel the following stylistic figures were identified:

a) anaphora: a syntactic device involving the repetition of a word phrase at the beginning of successive phrases or clauses, e.g. "Discover the magic of cooking. Introducing the new USHA cooktops, that make cooking a truly magical experience (USHA Cooktops); "Share moments. Share life" (Kodak); "Outwit. Outplay. Outlast" (Survivor); A different kind of company. A different kind of car" (Saturn); "Give artisanal... Give whimsical... Give local... Give exceptional"(Oakland Museum of California);

b)epistrophe:a word or expression is repeated at the end of successive phrases, clauses or lines . E.g. "Keeps going and going and going" (Energizer); "I'm a Pepper, he's a Pepper, she's a Pepper, we're a Pepper. Wouldn't you like to be a Pepper, too?" (Dr Pepper); 
c) anthimeria: a syntactic device based on conversion, i.e. the substitution of one part of speech for another, for example a verb for a noun and vice versa. E.g. "Welcome to fabulous" (ULTA); "Spread the happy" (Nutella); "Where better happens" (Sears); "Unlock your more" (Fiat); "The future of awesome" (Xfinity);

At the semasiological level:

a) homophonic and homonymous puns: "Haier and higher" (Hair household appliances). "Have a nice trip, buy-buy" (An advertisement for a supermarket in which "buy-buy" is relevantly used instead of "bye-bye");"Every kiss begins with Kay" (Kay Jewelers); "Have you met life today?" (MetLife);

b) semantic puns: "Range Rover: It's how the smooth take the rough"; "When the world zigs, zag" (Bartle Bogle Hegarty); "How do you spell relief? $R-O-L-A-I-D-S$ " (Rolaids); "GoodNites mean good morning" (Kimberly-Clark Corp.'s GoodNites absorbent underpants for children);

c) rhetorical questions, particularly those of second-person reference: e.g. "How Big Can You Dream?" (Cadence);"Where's the beef?" (Wendy's); "It is. Are you?" (The Independent); "Is it in you?" (Gatorade);

d) metaphor is used in advertising due to its ability to represent concepts while facilitating learning about the product's or service's brand; and the more time is spent interpreting the message, the more its meaning is internalized: e.g. "At the heart of image" (Nikon); "Slicing Up Freshness" (Arby's); "The Heartbeat of America" (Chevrolet); "Time is the new currency" (JWT); "Think Outside the Bun" (Taco Bell); "Roses grow on you" (Cadbury's chocolates).

e) simile: a figure of speech that explicitly compares two things using connecting words such as "like", "as", etc., often utilized by advertisers to highlight the features of the product. E.g. "A micro spring as thin as hair. A roller ball almost as hard as a diamond. A technology that adapts to you" (Add Gel Pen). E.g. "Like a Good Neighbor, State Farm is There" (State Farm)

f) hyperbole: "Pioneer: Everything you hear is true" (Pioneer).

g) semantic ambiguity, polysemy: e.g."Get $N$ or Get Out" (Nintendo 64); "Let's make things better" (Philips); "Every Little Helps", (Tesco). Semantic ambiguity is primarily needed to avoid any possible legal liability of the company being advertised; b) puns: e.g. "When it rains, it pours" (Morton Salt); "Leave nothing" (Nike); "Brutal simplicity of thought" (M\&CSAATCHI "The disruption agency" (TBWA); "When there is no tomorrow" (FedEx); "The last place you want to go" (Dixons; U.K. online store);

h) antithesis: a striking contradiction of ideas or words used within one statement.E.g."Stop dreaming. Start working" (Nike); "Come as a student leave as a manager" (Institute of hospitality and management);"Beauty outside. Beast inside" (Apple); "American by birth. Rebel by choice" (Harley-Davidson Motorcycles);"A sandwich is a sandwich, but a Manwich is a meal" (Manwich).

i) chiasmus - a rhetorical device in which two or more clauses are balanced against each other by the reversal of their structures. E.g. "You don't need to get a phone, you need a phone that gets you" (HTC); "I am stuck on Band-Aid, and Band-Aid's stuck on me" (Band-Aid brand adhesive bandages);

g) ellipsis: "Does she.. or doesn't she?" (Clairol).

Even though advertising slogans are usually quite short, their translation is often a great challenge due to some extralinguistic features, such as specific cultural background. In oral communication a person can be convinced as a result of the interlocutor's charm, tone, or the lyricism of the statement. Devoid of such personal contact with the addressee, the author of the advertising text tries to create the situation of personal communication, to make the text more emotional with the excitement of oral speech, allowing him to establish psychological contact with the addressee. Emotional tension is created in advertising text by means of: 1) the introduction of the personal pronoun in the second person into the title and body of the text, which limits the act of communication to one author-addressee pattern, gives this act of communication a personal, confidential character, helps the author to establish psychological contact with the addressee; 2) the widespread use in advertising text of the author's "question-and-answer" method as a form of creating an environment for direct conversation with the reader; 3 ) the use of a special stylistic device called "discontinuum", which gives increases the emotional character of the text.

Advertising contents can reveal a colourful historical imagery and mainstream ideologies which in turn react to the human attitudes, cognition and behaviour of advertising. H. Fan [4] states that the process of its interpreting is pragmatic, and it therefore needs a consideration of both individual situations in advertising and the social ideology. Advertisement is the carrier of culture, and can mirror current life, ideas, create power to shape social life and ideas, and influence culture $[7,3]$. While advertising images and artistic performance remain unchanged, it is the test of the advertisement that is translated and often subject to adaptation.

Two basic approaches are generally distinguished in advertising translation - a) authenticity up to the preservation of the syntactic structure of the original and the actual literalism, and b) free adaptation, suggesting a more creative interpretation of the original. Whatever the approach, adequate translation of advertisement should carry out its basic functions, i.e. overt economic function which makes the target audience want to buy things; and the ideological function that makes the recipients feel like "individuals in perpetuating the ideas which endorse the very economic basis of our society" [10].

The main problem that occurs in translation of the English advertising text is that usually the length of the translated text often exceeds the length of the original phrase. The reason is in the typological differences between Ukrainian and English. English belongs to analytical languages, while Ukrainian is classified as synthetic. This means that those meanings that are expressed grammatically in English (that is, through changes in the formal characteristics of words) are 
transmitted in Ukrainian through a combination of meanings of several words.

Conclusion. Stylistic devices are inherent to the strategy of persuasion of advertisement. Relevantly chosen stylistic figures in advertising slogans implicitly encourage the consumers to purchase a particular product or service. The research has shown a great range of stylistic devices used in English advertising slogans. The study of the selected advertisements revealed the following groups of stylistic devices:an- tisthecon, onomatopoeia, consonance, assonance, alliteration; anthimeria, epistrophe, anaphora; ellipsis, chiasmus, antithesis, hyperbole, simile, metaphor, rhetorical questions, semantic ambiguity, polysemy and puns.

Further research, particularlyin sociolinguistic domain, may contribute to unfolding the correlation between linguistic and extralinguistic features of advertising and its efficiency in terms of fulfilling its marketing objectives.

\title{
REFERENCES
}

1. Cook, G. (2001). The Discourse of Advertising. London: Routledge. 256 p.

2. Chugh, A., Sharma A.. Unfolding the Linguistic Features of Newspaper Advertisements in India. URL: https://files.eric.ed.gov/fulltext/EJ1128017.pdf (accessed 14.08.2018).

3. Dyer, G. (1988). Advertising as Communication.London: Routledge. 230 p.

4. Fan, H.Strategies for Translation of English Commercial Advertisements from the Intercultural Perspective. URL: https://file.scirp.org/pdf/JSS_2017110713505917.pdf (accessed 15.08.2018).

5. Leech, G. N. (1966). English in advertising. A linguistic study of advertising in Great Britain. London: Longman. $210 \mathrm{p}$.

6. Lin, S. (2012). Research for Effects of Product Placement Advertisements Regarding Consumer's Value. Advanced Materials Research. Vol. 452-453, P. 1133-1136.

7. Liu, H. (2006). Advertisement Aesthetics. Central Radio \& TV University Press 2011. 233 p.

8. Myers, G. (1997). Words in Ads.London: Hodder Arnold. 232 p.

9. Rein, D. P. (1982). The language of advertising and merchandising in English.New York: Regent.118 p.

10. Williamson, J. Decoding Advertisements. Ideology and Meaning in Advertising. URL: http://www.charlesacramer.com/ sf1110/ewExternalFiles/Williamson,\%20Decoding\%20Advertisements\%20smaller.pdf. (accessed 16.08.2018).

\section{СТИЛІСТИЧНІ ОСОБЛИВОСТІ АНГЛОМОВНИХ РЕКЛАМНИХ СЛОГАНІВ}

\author{
Зембицька Марина Володимирівна, Мазур Юлія Ярославівна \\ кандидати педагогічних наук, доченти \\ кафедри практики іноземної мови та методики викладання \\ Хмельницького національного університету, вул. Інститутська, 11, Хмельницький, Украӥна
}

\begin{abstract}
У статті розглянуто основні лінгвістичні особливості рекламних слоганів, стилістичні прийоми та фігури, щз найчастіше використовуються у сучасних англомовних комериійних рекламних слоганах на морфологічному, лексичному та синтаксичному рівнях. У дослідженні висвітлено результати аналізу довільної добірки з понад 100 рекламних слоганів. Виокремлено низку критеріїв ефективності рекламних текстів: здатність привертати увагу, легкість прийняття на слух/читабельність, запам'ятовуваність та сила маркетингового впливу, а також окреслено вимоги, яким вони повинні відповідати: лаконічність упоєднаннізізначною емоиійністю;зосередженість на основній комериійній пропозииії;нескладналексика, яка легко запам'ятовується $і$ легко перекладається. Особливу у статті увагу приділено стилістичним засобам досягнення переконливості рекламних слоганів та їх впливу на реципієнтів, ефективність якого є результатом обтрунтованого вибору стилістичних прийомів та фігур. Розглянуто два основні підходи до лінгвістичного аналізу реклами: соиіолінгвістичний та психолінгвістичний. Обидва розглянуті підходи даютьпідстави припустити, що існує певна взаємозалежність між ступенем переконливості реклами та мовними засобами, щьо у ній використовуються. Аналіз добірки рекламних слоганівдав змогу виокремити групи стилістичних прийомів,риторичних фігур та тропів на різних рівнях. Зокрема, на фонологічному рівні були виявлені: антистекон (метаплазм заміщення), ономотопоея, консонанс, асонанс, алітерація; на лексичному рівні у добіриі рекламних слоганів було проаналізовано: антимерію, епістрофу, анафору; на семантичному/прагматичному рівні знайдено приклади вживання: еліпсису, хіазму, антитези, гіперболи, порівняння, метафори, риторичногозапитання, семантичної невизначеності, багатозначності та каламбуру. Запропоновано класифікацію стилістичнихприйомів, щцо використовуються в рекламних текстах, з їх розподілом на: прийоми повторення; прийоми створення метафоричної ситуації, яка провокує реакцію реципієнта; складні стилістичні прийоми, щчо охоплюють як повторення, так і семантичні варіації. Одним із завдань дослідження є висвітлення окремих аспектів сприйняття та інтерпретаиії рекламного дискурсу.
\end{abstract}

Ключові слова: реклама, слоган, стилістичний прийом, стилістична фігура, троп, рекламний дискурс. 